Changing ideological and implementational spaces for minoritised languages in Higher education: Zapotequización of language education in Mexico

Haley De Korne (corresponding author)

Center for Multilingualism in Society across the Lifespan

University of Oslo

Blindern

0317 Oslo, Norway

Email: haleyjd@iln.uio.no

Mario E. López Gopar

Faculty of Languages

Universidad Autónoma Benito Juárez de Oaxaca

Avenida Universidad SN, Col. 5 Señores

68120 Oaxaca, Mexico

Email: lopezmario9@gmail.com

Kiara Rios Rios

Faculty of Languages

Universidad Autónoma Benito Juárez de Oaxaca

Avenida Universidad SN, Col. 5 Señores

68120 Oaxaca, Mexico

Email: kiarariosrios@gmail.com 
Acknowledgements: The authors wish to acknowledge and thank the students and members of the Faculty of Languages who have participated in and supported the Zapotec program. De Korne would like to acknowledge that the work of this article was partly supported by the Research Council of Norway through its Centres of Excellence funding scheme, project number 223265, and through a fellowship from the Smithsonian Institute Department of Anthropology.

\title{
Changing ideological and implementational spaces for minoritised languages in Higher education: Zapotequización of language education in Mexico
}

\begin{abstract}
:
Indigenous languages of Mexico have largely been excluded from formal education spaces. This ethnographic action research study highlights a context where Diidxazál Isthmus Zapotec, an Indigenous language of Oaxaca, has recently begun to be taught in Higher education. We examine the ways that administrators, the teacher, and students in these classes have collaborated to create a new space within the institution. By tracing the power dynamics behind the implementational and ideological efforts that have made this possible, we aim to provide insight into the social change underway in this setting, as well as the concrete steps taken in the creation of this pluralist space for Indigenous language learning. We conclude with discussion of the collective engagement that has been necessary in order to foster and develop a community of Indigenous-language learners, and the challenge of going beyond tokenistic inclusion of minoritised languages in education.
\end{abstract}

Keywords: Indigenous languages, Mexico, Higher education, Language Ideologies 


\section{Introduction}

Colourful paper flags have been hung in the common area of the Faculty of Languages in the largest public university in Oaxaca, Mexico. Dozens of undergraduate students are busy setting out tables with vocabulary games and regional food prizes designed to teach Isthmus Zapotec or Diidxazá, an Indigenous language of their state, to their fellow students. Some of the students have a heritage connection to the language, while many do not; most have been studying Diidxazá at the Faculty for 2 semesters. They created the games themselves, with guidance from their teacher, as well as donating their time and money to prepare decorations and prizes for the event. For several hours this boisterous, cheerful group fills the central common area of the Faculty, giving a presentation of Diidxazá poetry and art, and teaching fellow students through games and an introductory workshop lead by two advanced students. Numerous students, teachers and administrators from the Faculty attend and applaud the event. (De Korne field notes, 3 May, 2015)

This event exemplifies the visibility and acceptance of the teaching of the Isthmus Zapotec language in a higher education setting in the southern Mexican state of Oaxaca, or in other words the zapotequización (zapotec-isation) of a university space. Although Oaxaca is home to many Indigenous languages, teaching an Indigenous language in formal education is rare, and prejudice against Indigenous languages remains widespread in society. The case of Diidxazá, also called Isthmus Zapotec or simply Zapotec ${ }^{1}$, is no exception. The Diidxazá classes and public

\footnotetext{
${ }^{1}$ Zapoteco del Istmo (Isthmus Zapotec), Zapoteco (Zapotec) and Diidxazá are all common names for this language. This is one of roughly 62 variants of Zapotec spoken in Oaxaca (Instituto Nacional de Lenguas Indígenas (INALI)
} 
event described above therefore represent a significant shift in the practices of the Faculty of Languages of the Universidad Autónoma Benito Juárez de Oaxaca (UABJO), where they occurred. This paper explores the shifts in practice and in ideology which made it possible for an event such as this to occur in a space that has largely been devoted to the teaching and learning of English and other European languages. We examine the ways that administrators, the teacher, and students in these classes have collaborated to create a new space within the higher education institution.

Education institutions around the world have promoted certain languages over others, contributing to language hierarchies and the minoritisation or differential valuing of certain languages. Researchers in the domains of sociolinguistics, applied linguistics, bilingual education and linguistic anthropology, among other fields, have examined some of the factors and processes which contribute to the creation of language-related inequalities in education, as well as efforts to counter these inequalities (e.g. Fishman 1991; Cummins 2000; Hornberger 1991; Heath 1982). Socially-engaged language research, such as Pennycook's (2001) approach to 'critical applied linguistics' and Piller's (2016) 'applied sociolinguistics' have further shed light on the power dynamics which influence linguistic choices and practices. There is a need to consider how scholarship can go beyond pointing out the 'errors' inherent in inequalities, and engage in changing power structures which perpetuate such inequalities (Lewis, 2018; see also responses to this discussion paper in Language in Society 47(3)). Our case study contributes to this interdisciplinary domain of research by examining social change in language education from institutional and participant perspectives; we combine action research and ethnographic data in

2008). Within the university environment the term Zapoteco is most commonly used, however in this paper we use the terms Diidxazá or Isthmus Zapotec in order to avoid confusion and over-generalization in regards to other varieties of Zapotec. 
order to analyse the ideological and practical strategies which have been significant in an initiative to include an Indigenous language into an elite higher education space. By analysing the influential factors in a case of social change from a critical applied linguistic perspective, we aim to inform other pluralist education initiatives as well as future research into changing language hierarchies.

We begin with a discussion of language education and inequalities, illustrating our theoretical orientation in relation to the history and present of the context of study, and presenting the questions which we seek to answer in this paper (section 2). We then describe our methodological approach and roles as researchers and practitioners in this context (section 3). Sections 4 and 5 analyse the practical and ideological changes which have contributed to the inclusion of a minoritised language institutionally and in the classroom. Section 6 probes the motivations and experiences of students who have chosen to participate in Diidxazá classes and discusses the ideological complexity that characterises efforts to promote Indigenous languages, including the risk of tokenising and patronising languages and speakers. In the conclusion (section 7) we summarize the contributions of the study which we hope may be useful in projects which seek to counter language hierarchies in education elsewhere.

\section{Castellanización: Language education and Indigenous languages in Oaxaca}

The exclusion of Indigenous languages from formal education, and a corresponding promotion of linguistic and cultural homogeneity has been a common practice among nation-state governments in many parts of the world (Tollefson 1991). The promotion of Spanish and exclusion of Indigenous languages through schooling, or castellanización (Spanish-isation), has been well-documented in Mexico in general (Hamel 2008; Heath 1972) and in Oaxaca in 
particular (Maldonado Alvarado 2002; López-Gopar, Morales, and Jiménez 2014).

Castellanización has included not only a shift to speaking Spanish, but also a shift towards Eurocentric ideologies of language and literacy which devalue the multiliteracies present in Indigenous communities (López Gopar 2007).

Long before the Spanish invasion, the Zapotec developed sophisticated pictographic and semi-phonetic writing while controlling an empire that governed much of what is now Oaxaca state from around 500 BCE to 900CE (de la Cruz, 2008; Romero Frizzi, 2003). Nonetheless, this illustrious history has all but been erased from popular understandings of Zapotec language and culture today, and has little representation in most classrooms. Although there is a nominally bilingual education system in Mexico, most schools focus on transitioning Indigenous language speakers to Spanish, without developing bilingual or biliterate skills (García and Velasco 2012; Coronado Suzán 1992). Through both the exclusion from physical spaces, such as schools, and through ideological devaluation, Indigenous languages such as Diidxazá have come to be considered dialectos (dialects), less valuable than the 'languages' which are recognized by nation-states and taught in schools.

In the post-World War II human rights era, efforts to create new spaces for marginalized languages have been undertaken in both large-scale and small-scale ways, from national and international declarations, to the creation of immersion programs, and socialization choices made by individual families (Skutnabb-Kangas and Phillipson 1994; Hinton 2013). For example, the Mexican law on the linguistic rights of Indigenous peoples (Ley General de Derechos Lingüísticos de Los Pueblos Indígenas 2003) created a foundation for change in educational ideology and practice, although this recognition has yet to significantly change the practice of excluding Zapotec and other Indigenous languages from schools at the local level (López-Gopar 
et al. 2013). Ongoing socio-economic changes influence how languages which were previously seen as worthless within nation-state ideologies may come to be viewed as commodities, or something which will have a tangible social or economic value for users in the global-local era (Flubacher and Del Percio 2017; Gal 1989). Being multilingual and thus able to shift flexibly among languages, once viewed negatively by homogenizing education systems, has come to be valued in the context of economic mobility and worker flexiblization (Flores 2013). New ways of valuing and 'reentextualizing' minority languages in tourism and commercial discourses, as discussed by Pietikäinen et al. (2016) in relation to minoritised languages in European contexts, are changing the ideologies which speakers and non-speakers hold in relation to these languages. The commodification of Indigenous languages and cultures for the purposes of display and marketization in Latin America has been widely critiqued by scholars who point out that Indigenous communities often receive little material benefit as a result (Hale 2005; Comaroff and Comaroff 2009; Overmyer-Velázquez 2010). It is clear that ideologies around minoritised languages are changing; however it is not clear whether the new forms of value will remain tokenistic and rhetorical only, or whether they will contribute to changing material inequalities.

Within the important social gate/keeping space of Higher education there are multiple ways that Indigenous languages have been promoted. Linguistic research on Indigenous languages has typically focused on languages as objects (forms and texts), although there are exceptions where Indigenous languages are taught as subjects with the goal of achieving communication among learners (Hornberger, De Korne, and Weinberg 2016; Mendoza-Mori 2017). Providing quality education for Indigenous language teachers is a challenge which institutions in a variety of places around the world are working to address (Whitinui, Rodríguez de France, and McIvor 2018). Educators working in this area argue that it is necessary for higher 
education institutions to collaborate with Indigenous communities and to adjust the traditionallyexclusionary characteristics of the institution in order to provide accessible and effective programs (Czaykowska-Higgins et al. 2017).

In order to promote greater use and recognition of Indigenous languages in particular and language diversity in general, Hornberger (2002) discusses the need to foster both 'ideological' and 'implementational spaces for multiple languages, literacies, and identities in classroom, community, and society' (p. 45). She notes that achieving successful Indigenous language education requires shifts in ideologies, or beliefs and perceptions about Indigenous languages, as well as shifts in how education is implemented, such as the practical elements of curricula, programs, and institutional governance. Where the opportunity exists to implement Indigenous language education within an institution but participants do not value Indigenous languages ideologically, it is unlikely that the endeavour will succeed. As Zavala (2013) notes in the context of Quechua language education in Peru, political support must be accompanied by a positive and inclusive ideological environment in order to facilitate the engagement of learners. Likewise, although discursive recognition and positive ideologies exist, many essential practical necessities such as teacher training, didactic resources, and stable institutional support may remain lacking.

\subsection{Isthmus Zapotec education}

Isthmus Zapotec is accorded 1 hour per week and no resources at 'bilingual' schools attended by a minority of children; in mainstream schools it is excluded. The inclusion of the Isthmus Zapotec in education is rejected as worthless by some social actors; at the same time, others view it as an important element of identity, and some see it as a possible resource for economic and 
even geographic mobility (De Korne 2017c). Ideological support for Isthmus Zapotec is strengthened by initiatives from non-official actors with relatively high social status and visibility. There is an on-going Isthmus Zapotec literary movement dating back to the late 1800s, with writers whose works are known locally, nationally, and occasionally internationally (de la Cruz 2013; Pineda 2014). In 1956 a 'popular alphabet' was developed at the initiative of Isthmus Zapotec writers with the participation of linguistics (Pickett 1993; La Sociedad ProPlaneación del Istmo 1956). This alphabet is currently in use, and promotes the representation of dialect diversity through a common inventory of graphemes, or what can be called a polynomic norm (Marcellesi 1983; Jaffe 2003) (for more on the history and current practice of Zapotec writing see (Pérez Báez, Cata, and Bueno Holle 2015; De Korne 2017a). Numerous Zapotec writers and musicians are well-known and admired in popular society, both those working with more traditional genres as well as young hip-hop musicians and graffiti artists. While the focus in this paper is on actors and practices within the Higher education space, it is important to note that popular-culture role models indirectly contribute both logistical or implementational support (in the form of the texts, music, and events which they create and which learners make use of) and ideological support (in the form of the positive, nuanced discourses which their work articulates about the contemporary significance of Diidxazá).

The use of Isthmus Zapotec in a university setting is thus occurring against the backdrop of several centuries of exclusionary ideologies, with official inclusionary ideologies emerging in the late $20^{\text {th }}$ and early $21^{\text {st }}$ centuries, and new socio-economic influences ongoing. The Faculty of Languages of the UABJO located in Oaxaca City ${ }^{2}$ has traditionally focused on the study of

\footnotetext{
${ }^{2}$ There are three campuses of the Faculty of Languages of the UABJO. Diidxazá has been taught at two of these campuses, the main campus in Oaxaca City, and the satellite campus of Tehuantepec, since 2013. This article
} 
European languages, especially English. Aside from required English courses, students choose a second language to study to a lesser degree, usually French or Italian depending on what is offered at that time. Academic languages are periodically celebrated in special presentations or events. For example, students offer their peers the opportunity to 'Travel to Ireland without a visa or a passport' by decorating the common area of Faculty, and providing food, music and other activities designed to give a taste of the place where the language is spoken. In the autumn of 2013 Diidxazá was offered as an additional language for the first time. After an initially small group of students enrolled in the first year, a significant increase in enrolment in the autumn of 2014 helped to facilitate the well-attended event organized to celebrate Diidxazá in the spring of 2015, described in the opening vignette. This event was similar in format and style to the activities organized around other languages in the Faculty—with the exception that for the first time a local language and culture was being highlighted, and some of the participating students had family connections to the language. Over the course of a few semesters this Indigenous language had come to hold a recognized space amongst the other languages of the Faculty.

In order to understand how this occurred, we will trace some of the changes which contributed to this perhaps small, yet concrete social change in the everyday hierarchy of languages in Oaxaca. Specifically, we analyse:

1. What implementational and ideological changes occurred in institutional practices? (section 4)

2. What implementational and ideological changes occurred in classroom practice? (section 5)

3. What motivated students to participate in this program and the changes it embodies? (section 6) focuses on the process and experiences of participants in the Diidxazá program at the Oaxaca City campus specifically. For further discussion of the program at the Tehuantepec campus see De Korne (2016). 


\section{Ethnographic action research case study}

This paper analyses the observations and experiences of the education practitioners in a specific context in conjunction with field notes, documents, and interviews, employing an ethnographic approach to action research (McIntyre 2008), also referred to as ethnographic monitoring (Hymes 1980; De Korne and Hornberger 2017). Our analysis of this case draws on our experiences as participants in the Diidxazá program, with different roles and perspectives.

Mario López Gopar is a scholar and educator from Oaxaca City. He is one of the core faculty members at the Faculty of Languages where he teaches in the BA in Enseñanza de Lenguas (Language Teaching/ Learning), the MA in Educación Crítica de Lenguas (Critical Language Education) and the PhD program in Estudios Críticos de Lenguaje (Critical Language Studies). He has also worked in the US and Canada, where he completed his doctorate in Second Language Education at the University of Toronto. He conducts critical ethnographic action research and examines opportunities for decoloniality in English education.

Kiara Ríos Ríos is a scholar and educator from the Isthmus Zapotec-speaking community of La Mata in the south of Oaxaca State. She teaches Diidxazá and English at the UABJO, where she studied with López Gopar and completed her BA in 2014. She is currently pursuing her MA in Critical Language Education, focusing on the development of the Diidxazá program within the university.

Haley De Korne is a scholar and educator originally from Michigan, USA, and has taught topics in Sociolinguistics within the MA and BA programs at the Oaxaca City and Tehuantepec campuses of the UABJO Faculty of Languages. Between 2013 and 2015 she observed Isthmus 
Zapotec education in formal and non-formal education settings, including the UABJO, as part of her doctoral research in Educational Linguistics.

This paper draws upon documentation of the program between 2014 and 2017, including curriculum and assessment documents, photos, and video clips, as well as field notes and interviews. The perspectives of student participants are included through confidential interviews that were conducted by De Korne with a voluntary sample of students, while the perspectives of administrator and teacher are included directly by López Gopar and Ríos Ríos. By bringing together these different perspectives, we analyse factors which have been instrumental in the development and maintenance of this program, and reflect on remaining challenges.

\section{Changing spaces within the institution}

The Diidxazá program emerged in a temporary implementational space within the institution, and has moved from experimental status to being recognized as an additional language alongside European languages. We highlight some of the practical and ideological challenges during this process, and approaches to addressing them.

4.1 Practical changes: When, where, and how

Diidxazá was first brought into the curriculum as an experiment, or an afterthought, and over time has come to hold the same institutional weight as other languages. When and where Diidxazá teaching takes place, and how much publicity it is given, are key examples of this change in status from experiment to norm. Ríos Ríos first taught Isthmus Zapotec to UABJO students when invited to do so by López Gopar in the context of a class exercise, with no expectation that the students would eventually continue to study the language or be evaluated on their competencies. When López Gopar subsequently advocated to establish a Diidxazá class 
officially, this was accepted by other faculty members but it was scheduled for three consecutive hours on Friday afternoons, an undesirable time in comparison to other optional language classes. Additionally the course offering was not advertised to new students as other language courses were. The unattractive scheduling and lack of visibility contributed to a low enrolment in the first year, and the small number of students meant that it was the last to be assigned a space, with the assumption that it did not need a whole classroom. Although Diidxazá had been allowed into the educational space, it was positioned as marginal and of lower status.

Creating greater legitimacy for the class in the second year it was offered (2014-2015) was achieved firstly through more effective promotion. With the continued support of Authro 2, Ríos Ríos and some of her students participated in the new student induction program, resulting in a substantial number of students who chose to enrol. This meant that the class was given a normal classroom and a more desirable schedule. As Ríos Ríos has continued to offer classes up to level 8 (one level per semester) for continuing students, Diidxazá classes have come to take up more time and space in the Faculty of Languages' curricular offerings. The participation of Diidxazá students in public events within the Faculty, such as the annual Christmas Carol competition and special events such as the interactive fair described in the opening of this paper, has also increased the visibility and acceptance of the language. Although there are more students who continue to choose French or other European languages, the students who choose Diidxazá are now able to do so without making a choice that is markedly less convenient or less supported.

4.2 Ideological changes: Legitimate language, legitimate speakers 
When the course was introduced, some members of the Faculty community questioned whether Diidxazá would have sufficient content for 8 semesters, had a grammar which could be taught systematically, or a writing system. These concerns are common and pervasive in Indigenous language education initiatives in Mexico, where even more prejudiced discourses circulate in popular media and society without censure. This ideological climate has lead the majority of Mexicans to believe that Indigenous languages are less complex than European languages. In the case of Diidxazá, the fact that several Zapotec writers have gained national and international fame for work published bilingually in Diidxazá and Spanish, as mentioned in section 2, helped to establish the legitimacy of the language through use in literary texts. In this sense, Diidxazá gained some status within the institution through alignment with the ideological norms of European languages and literacies, and through support from language and culture advocates outside of the university. Importantly, however, within the classroom the Eurocentric focus on grammar and literary genres have not dominated, as discussed in section 5 below. Ideological norms about bilingualism also posed a challenge to the recognition of Ríos Ríos as a competent speaker (and thus teacher) of Diidxazá. The monolingual norms promoted by nation-states and educational institutions have fostered a belief that bilingual speakers have one true dominant language, an assumption that is reinforced in language-related disciplines by concepts like 'native speaker', 'L1', and Chomsky's (1965) homogenous speech community. Ríos Ríos notes that there is a stereotype in Oaxacan society that 'true' or 'authentic' Indigenous language speakers will speak limited Spanish, and that her competence in Spanish has been pointed to as a reason to doubt her Diidxazá abilities. While critique of the native speaker bias is well-established in language education scholarship (e.g. Canagarajah, 1999; Heller, 1999), a monolingual bias predominates in the perspectives of individuals as well as in institutional structures in Oaxaca. 
Additionally there is a different perspective towards forms of bilingualism that are perceived as elite (such as Spanish and English) and forms of bilingualism that are devalued (such as Spanish and Indigenous languages), where the former is seen as an asset, and the latter is not (López Gopar 2016; López-Gopar and Sughrua 2014). These ideological barriers were addressed in discussions with members of the Faculty in order for a bilingual speaker/ teacher to begin to gain equal recognition in this context.

With the establishment of structural supports including equal credit, classroom space, timetabling, publicity, and teacher recognition, the institutional environment of the Faculty of Languages has allowed the Diidxazá program to expand and in turn to gain social status. The status of other Indigenous languages within the Faculty is a concern, as Diidxazá is one of many locally-relevant languages. With the generally improved ideological climate in favour of Indigenous languages, the intent of Faculty members is to continue to welcome Indigenous language speakers to teach when and where possible.

\section{Zapotequización of the classroom space}

The success of the Diidxazá classes as a pedagogical space has also played a key role in reinforcing the acceptance of the Faculty community and all those participating in it. Ríos Ríos created a teaching plan informed by her training in language (in particular EFL) pedagogy. Her goal is for students to communicate with Diidxazá speakers, and thus she focuses on topics and activities of relevance to her students (section 5.1) and the current communicational norms of the Diidxazá speech community, including translanguaging and dialect diversity (section 5.2).

5.1 Practical changes: Learning goals, activities, and assessment 
Ríos Ríos has designed syllabi according to the framework of the Faculty of Languages; however her pedagogical approach differs from that used in other language courses which are geared towards student success in standardized written assessments, such as the TOEFL, and which can draw upon an extensive offering of textbooks and resources. Her first semester students are expected to produce and present an 'identity text', an activity promoted by López Gopar and other scholars working in multilingual education (e.g. Bernhard, Cummins, \& Campoy, 2006; Cummins \& Early, 2010). Students are positioned as speakers of Diidxazá in this way from the first semester and are encouraged to ask for vocabulary to talk about the subjects that interest them. Ríos Ríos does not enforce spelling norms in the classroom, instead encouraging her students to write in a way that helps them to remember the sounds.

In the second semester and thereafter, Ríos Ríos engages students directly in the production of learning materials, and in choices about syllabus design and content. She uses games, role-plays, pair and group exercises, and songs to scaffold students' comprehension and production abilities. This also allows students with background knowledge of the language to draw on this resource as far as they are able. Students produce flashcards, games and texts as assignments, which are then shared among the classes. Assessment is based on participation, final identity texts produced on a different theme each semester and graded with a rubric, and several written vocabulary and grammar tests. Many of the activities used in class are drawn from global language pedagogy techniques, however the content and themes are focused on the local context. Ríos Ríos aims to meet the expectations of university students who are accustomed to certain classroom routines and products, while emphasizing communication abilities and themes which may be useful in future interactions.

5.2 Ideological changes: Translanguaging and being bidialectal 
Translanguaging with elements of Spanish is common in everyday Isthmus Zapotec speech, a phenomenon which is questioned by some students who have expectations of parallel monolingualism (Heller 1999), or complete autonomy among different languages. While scholars and some teachers actively promote concepts like flexible bilingualism (Blackledge and Creese 2010) and translingual practices (Canagarajah 2013), students and their social networks often maintain expectations derived from ideologies of language purism and monolingualism. Ríos Ríos promotes translanguaging as a norm by explaining to students that they will hear translanguaging frequently in Isthmus Zapotec communities, and they should not be ashamed to use it themselves in order to extend their communication abilities. Students become accustomed to 'zapotequized' words, or words from Spanish which have been adapted and changed through Zapotec phonology and morphology (see De Korne 2017b for further discussion of multilingual pedagogies in this context).

The presence of many different varieties of Zapotec within Oaxaca State, and within the Isthmus, is also part of the power dynamics in the instruction of Diidxazá. There are more speakers of Diidxazá than any other variety of Zapotec, and the culture of the Isthmus has been typified in the public imagination as boisterous, colourful, and creative. Students who have family connections to a different variety of Zapotec (one with fewer, if any, speakers) also find Diidxazá an appealing language to study. Within Diidxazá there are several dialect variants, and Ríos Ríos emphasizes the equality of these variants to her students, allowing them to use any variant they prefer. She teaches the variant of her village (La Mata/ Ixtaltepec) which has fewer speakers and less visibility than the variants of nearby Juchitán (the variant which was documented by the Summer Institute of Linguistics and subsequent linguists, forming the reference for most existing text materials (e.g. Pérez Báez, 2015; Pickett, Black, \& Cerqueda, 
2001) and Tehuantepec/ San Blas, the traditional power-centre of the region). Ríos Ríos has adapted texts from other varieties into her own, and finds that students are interested and willing to learn her variety, and to accept the presence of dialect diversity within Diidxazá. The 1956 'popular alphabet' norm explicitly sanctions the representation of different dialects (as mentioned in section 2), offering further legitimacy to this practice. What students would initially have viewed as 'speaking wrong', they come to understand as 'being bidialectal', a sophisticated linguistic concept which most classes teaching standardized European languages do not foster. Being taught that translingual practices and multilingual repertoires are legitimate is an especially valuable learning outcome among students who already have varying degrees of bilingualism or are in frequent contact with people who do.

Teaching these classes has required Ríos Ríos to do extensive research and reflection on communication practices in the Isthmus, and to develop a teaching approach which she feels is most appropriate to her students and to the current speech community. She bridges between the critical language pedagogies and theories that she studies and works with as a member of the Faculty of Languages, and her knowledge of how communication occurs in the Isthmus in order to create an inclusive Diidxazá learning environment within the university.

\section{Community participation in change}

In order to create new practices and ideologies within the Faculty of Languages, the engagement of actors holding different levels of authority and different roles within the community has been essential. The contributions of administration-level actors, such as López Gopar, and actors with knowledge of the language community outside of the institution, such as Ríos Ríos, are equally crucial in the development of a more inclusive or pluralist space within the institution, as 
illustrated in sections 5 and 6 above. Additionally, neither the institutional nor classroom spaces described above could be successful without the willing participation of students, and to a lesser degree the acceptance of their peers and social networks. This section examines some of the motivations of students who chose to participate in Diidxazá classes, and their insights about how these classes are viewed by others around them. The perspectives included here are drawn from confidential interviews that De Korne conducted with a voluntary sample of students and are analysed in the light of observations of the Faculty community. ${ }^{3}$

\subsection{Personally-relevant participation}

Several of the students who have been motivated to study Diidxazá mentioned the personal relevance of the language as a part of their family history, or previous experiences they have had as Oaxacans. Although the opportunity to study Diidxazá formally was new, for many students the language is viewed as part of their environment and heritage, and thus a topic of personal interest. As one student commented:

UO3: [...] en principio agarré italiano. Eh... fui a dos clases. Hum... y no iba entendiendo mucho [...] Pero fue cuando llegó el maestro Bill y él fue él que dijo que se había abierto una nueva lengua adicional que era el zapoteco. Entonces pues dije, me acordé, ¿no? cuando mis papás me decían una palabra en zapoteco, que yo--- hasta ese entonces no sabía cuál era su significado, ¿no? Que me decían el famoso “padxiuxi” [un

\footnotetext{
${ }^{3}$ Interviews were conducted in Spanish, all translations are ours. We do not use students' names in order to maintain confidentiality. Transcription conventions:

- /slashes/ are used to indicate overlapping speech between interviewer and interviewee.

- ...Three dots are used to indicate a pause.

- $\quad$--Dashes are used to indicate interrupted speech.

- $\quad[\ldots]$ Brackets with three dots are used to indicate an omission of the original transcript.

- [brackets] are used to indicate an editorial or translation insertion, such as a word that is implied but not actually present in the transcript.
} 
saludo en Zapoteco], ¿no? [...] Pero nunca supe qué significaba. Hasta que entré pues al curso, ¿no? entonces fue que me llamó la atención y dije: mejor voy a entrar, ¿no? y fue que me anoté y me cambié de... de lengua y este... y una vez que entré pues sí... [...] aprendes desde el primer semestre.

UO3: [...] in the beginning I chose Italian. Uh... I went to 2 classes. Um... and I wasn't understanding much [...] But that was when Professor Bill arrived and he, it was him who said that a new additional language had been opened which was Zapotec. So I said, well I remembered, right? When my parents would say a word to me in Zapotec that I-up until then I didn't know its meaning right? That they would say to me the famous "padxiuxi” [generic greeting in IZ], right? [...] But I never knew what it meant. Until I entered the class, right? So that was what called my attention and I said, it's better for me to enter [Zapotec] right? And that was how I signed up and I changed... languages and um... and once I entered [Zapotec] well yes [...] you learn from the first semester.

(Interview 9 May, 2014)

For this student the relevance of Zapotec to their personal experiences outside of the university drew them to make a choice different from most of their peers.

Within the class, all students noted the participatory and playful nature of activities as a factor motivating them to continue studying, and the fact that they experienced success as learners. One student noted in an interview that the teacher's love for the language is what made the class most enjoyable (CU1 5 April, 2017). Their participation and friendly cohesion as a group were evident in classroom observations, as was their growing competence in understanding and speaking Diidxazá. For example, in a class with students in their second year 
of studying Diidxazá, Ríos Ríos asked students to write about what they would change if they were director of the Faculty, and then talk about it in class. A discussion about university politics followed, with students and teacher talking about university admissions, exams, and other topics mainly through Diidxazá (De Korne Field notes 18 June, 2015). Contextually relevant topics such as this were successful in evoking both language production and meaningful communication among class participants.

\subsection{Encountering prejudice}

While the students who chose to participate in Diidxazá classes already had an interest and positive perspective towards Indigenous languages, they continue to be surrounded by peers and social networks that largely do not. They discuss how the Faculty of Languages has taken a stand to influence the awareness and attitudes of all students (whether they study Diidxazá or not), but that this awareness does not extend beyond the Faculty into the rest of the university, let alone into the rest of their social networks. The perspectives that students encounter include patronizing approval, ignorance, and mockery, as recounted by a student :

A: ¿Qué dice la gente cuando dices que estás lestudiando

zapoteco? ¿Qué reacción?/---

UO1: /No. ¡Se emocionan!/ No, no, no. Qué bonito, pero y--- siempre... pues me dicen: qué bonito que estés aprendiendo un dialecto.

\section{A: ¡Aaah!}


UO1: ¡Ay qué bonito, un dialecto! Y yo: no es un dialecto [risas]. Y este--- pero sí se... sí se sorprenden, ¿no? ¡No creían! ¿Por qué estás estudiando zapoteco cuando hay idiomas? Ellos, idiomas, ellos dicen. [...]

A: Y esas--- las personas que dicen por qué un dialecto cuando hay idiomas, ¿son... alumnos de la /facultad o qué?/---

UO1: /No./ Eh... pues son de la universidad pero estudian otras carreras. [...] Y pues ya... mis compañeros también no se dirigen a él como un dialecto. Porque aquí pues... de eso se han encargado, de enseñarnos que no es un dialecto, es /una lengua/--

\section{A: /Aquí en la facultad./}

UO1: Sí, aquí en la facultad. Ellos ya, pero de otros lugares no.

A: What do people say when you say that you're /studying

Zapotec? What reaction?/---

UO1: /No. They get excited!/ No, no, no. "How nice”, but and--- always... well they say to me: "How nice that you're learning a dialect".

\section{A: Ah!}

UO1: Oh how nice, a dialect! And I: "It's not a dialect" [laughs]. And um--- but yes they...yes they are surprised, right? Didn't believe it! "Why are you studying Zapotec when there are languages?" They, "languages", they say. [...] 
A: And these--- the people who say "why a dialect when there are languages, are... students from the /faculty or what?/---

UO1: /No./ Uh... well they are from the university but they study other programs.[...] And well now... my classmates also don't talk about it as a dialect. Because here well... they have taken that on, to teach us that it is not a dialect, it's /a language/---

\section{A: /Here in the Faculty/}

UO1: Yes, here in the Faculty. Them now, but from other places no.

(Interview 8 May, 2014)

Changing perspectives within the Faculty of Languages is already a substantial accomplishment, and one that can hopefully ripple outwards into students' families and their social networks. The fact that students receive positive responses from some people is important, even if these responses also display a lack of understanding of the difference between dialect and language, and a patronizing view of Indigenous languages as dialects.

Another student discussed their frustration with people who say that Indigenous languages are 'bonito', (a form of nice that is diminutive and/or intensified, depending on interpretation) but do not reflect this positive perspective in their actions. Although these people are assigning more value to Indigenous languages, it falls short of treating them with the same respect as European languages. The student argues that this kind of tokenistic or limited appreciation is insufficient to change social relations:

UO2: muchos dicen ... tenemos clases que tienen que ver con el medio. Entonces... luego dicen: no, es que hay que rescatar las lenguas. A mí me enoja mucho cuando empiezan a 
hablar así. Me enoja pero no tienes idea. ¿Por qué? Y yo--- más de una vez se los he dicho: ustedes hablan mucho de rescatar la lengua. De hablarla, de que qué bonitas son. ¿Cuántos hablan? Nadie. No los culpo de eso. La clase de zapoteco está abierta en la facultad. ¿Cuántos de ustedes van? Entonces no vengan a hablarme bonito cuando no... no son congruentes. [...] Y te reitero, yo sí me siento... con esta obl... yo me siento con esta obligación de rescatar el zapoteco pero siento que debe ser de una forma distinta. [...] Si pudiese yo primero comprenderlo y hablarlo perfectamente, entonces seguir ahora con los demás. $O$ sea, tengo que primero empezar con los que me rodean para entonces seguir, seguir, seguir.

UO2: Many say... we have classes that are about the environment [in Oaxaca]. So... afterwards they say: "No, it's necessary to save the languages". This makes me really angry when they start to talk like that. You have no idea how angry I get. Why? And I--more than once I have said to them: "You talk a lot about saving the language. About speaking it, about how 'nice' they are. How many of you speak? No one. I don't blame you for that. The Zapotec class is open in the Faculty. How many of you go? So don't come and talk to me about 'nice' when you... you're not congruent. [...] And I reiterate to you, I do feel... with this obl... I feel with this obligation to save Zapotec but I feel that it should be in a different way. [...] If I could first understand and speak it perfectly, then continue now with the rest [of the people]. So, I have to first start with those who are around me in order to then continue, continue, continue.

(Interview 8 May, 2014) 
This student points out that Indigenous languages may shift from being worthless to being something 'nice' which should be saved, however this will not necessarily mean that more people respect or participate in the speech community. As the new space of Diidxazá education emerges, further attention is needed to the ongoing shifts in ideology towards minoritised languages.

\section{Conclusion}

Through a discussion of the Diidxazá program at the UABJO we have noted the importance of engagement from a variety of social actors in order to address the implementational and ideological challenges inherent in the project of zapotequización; collaboration of actors with institutional power and actors with socio-linguistic knowledge has been crucial, as well as willing participation from the surrounding academic community. We have also highlighted strategic choices which lead to a functioning learning environment at the centre of the initiative, including aspects of program scheduling, space, visibility, and high pedagogical quality.

Ideologies towards Indigenous languages have clearly shifted in the Faculty in our observations, although Ríos Ríos notes that each generation of students enters with prejudices which have to be discussed anew. López Gopar likens the success of Diidxazá classes to the recent rise in popularity of the Oaxacan liquor Mezcal, along with certain clothing and music which were traditionally only made and consumed by campesinos (peasants), but are now widely popular in Oaxaca among locals and tourists alike. This kind of new-found caché, or social capital, may be a good antidote to the prejudice and exclusion that local languages, their speakers, and the products they make and consume have experienced under colonial and nationalist regimes. At the same time, as these hierarchies shift, it is important to remain 
attentive to unintended effects - in the case of Mezcal, effects such as ecological damage from intensified production and the involvement of large-scale producers which may harm small-scale producers. In the case of Diidxazá, causes for concern include the potential to be viewed as a 'nice' novelty worthy of conservation (rather than a modern, equal speech community), being granted a minimal, unsustainable space within the institution, and being judged negatively in light of institutional priorities which are shaped by a colonial heritage and a neoliberal present. The process of reentextualizing a minoritized language into an educational domain entails inherent ideological challenges, including debates over which language varieties are appropriate to be taught and who should have the authority to evaluate the outcomes.

Shifting social and institutional language hierarchies through plurilingual education remains an ideal with a moving target of success. The Diidxazá speech community and the university community both continue to undergo shifts in communication practices and perspectives, and facilitating education practices which are relevant to both these groups is not straightforward. Although implementational spaces are emerging, ideological spaces are hard to observe and document, as public rhetoric may not align with actions, and elements of old prejudices continue to resurface in new discussions. When peers say 'How nice that you're learning a dialect!' or 'Indigenous languages must be saved!' this is in some ways a positive outcome of efforts to promote plurilingual norms and linguistic equality. On the other hand, statements of support are unlikely to change power hierarchies if they are not accompanied by actions. For Indigenous languages and speakers to be valued - rather than patronized or exoticised-ongoing efforts to create new norms and new spaces of equal respect are essential. For the participants in this program, Indigenous language education is one avenue of action through which to participate in meaningful change. 


\section{References}

Bernhard, Judith K, Jim Cummins, and F Isabel Campoy. 2006. "Identity Texts and Literacy Development Among Preschool English Language Learners: Enhancing Learning Opportunities for Children at Risk for Learning Disabilities.” Teachers College Record 108 (11): 2380-2405.

Blackledge, Adrian, and Angela Creese. 2010. Multilingualism. London, UK: Continuum.

Canagarajah, Suresh. 1999. "Interogating The 'native-Speaker Fallacy': Non-Linguistic Roots, Non-Pedagogical Results." In Non-Native Educators in English Language Teaching, edited by George Braine, 77-92. London \& New York: Routledge.

- 2013. Translingual Practice: Global Englishes and Cosmopolitan Relations. New York: Routledge.

Chomsky, Noam. 1965. Aspects of the Theory of Syntax. Cambridge, Massachusetts: MIT Press.

Comaroff, John L., and Jean Comaroff. 2009. Ethnicity, Inc. Chicago: Chicago University Press.

Coronado Suzán, Gabriela. 1992. "Educación Bilingüe En México: Propósitos Y Realidades.” International Journal of the Sociology of Language 96: 53-70.

Cummins, Jim. 2000. Language, Power and Pedagogy: Bilingual Children in the Crossfire. Clevedon, UK: Multilingual Matters.

Cummins, Jim, and Margaret. Early. 2010. Identity Texts : The Collaborative Creation of Power in Multilingual Schools. Stoke-on-Trent, UK: Trentham Books. 
https://eric.ed.gov/?id=ED511425.

Czaykowska-Higgins, Ewa, Strang Burton, Onowa Mcivor, and Aliki Marinakis. 2017.

"Supporting Indigenous Language Revitalisation through Collaborative Post-Secondary

Proficiency-Building Curriculum." Language Documentation and Description 14. EL

Publishing: 136-59. http://www.elpublishing.org/docs/1/14/ldd14_07.pdf.

De Korne, Haley. 2016. Imagining Convivial Multilingualism: Practices, Ideologies, and Strategies in Diidxazál Isthmus Zapotec Indigenous Language Education. University of Pennsylvania: PhD Dissertation.

—. 2017a. “"That's Too Much to Learn': Writing, Longevity, and Urgency in the Isthmus Zapotec Speech Community.” In Standardizing Minority Languages: Competing Ideologies of Authority and Authenticity in the Global Periphery, edited by Pia Lane, James Costa, and Haley De Korne, 222-41. London, UK: Routledge.

_ 2017b. "The Multilingual Realities of Language Reclamation: Working with Language

Contact, Diversity, and Change in Endangered Language Education.” Language

Documentation and Description 14: 111-35.

—. 2017c. ““A Treasure' and 'a Legacy': Individual and Communal (Re)valuing of Isthmus Zapotec in Multilingual Mexico.” In Language, Education and Neoliberalism: Critical Studies in Sociolinguistics, edited by Mi-Cha Flubacher and Alfonso Del Percio, 37-61. Bristol, UK: Multilingual Matters.

De Korne, Haley, and Nancy H. Hornberger. 2017. “Countering Unequal Multilingualism through Ethnographic Monitoring." In Researching Multilingualism: Critical and 
Ethnographic Perspectives, edited by M. Martin-Jones and D. Martin, 247-58. London, UK: Routledge.

Fishman, Joshua. 1991. Reversing Language Shift: Theoretical and Empirical Foundations of Assistance to Threatened Languages. Bristol, UK: Multilingual Matters.

Flores, Nelson. 2013. “The Unexamined Relationship between Neoliberalism and Plurilingualism: A Cautionary Tale.” TESOL Quarterly 47 (3): 500-520.

Flubacher, Mi-Cha, and Alfonso Del Percio, eds. 2017. Language, Education and Neoliberalism : Critical Studies in Sociolinguistics. Bristol, UK: Multilingual Matters.

Gal, S. 1989. "Language and Political Economy.” Annual Review of Anthropology 18 (1). Annual Reviews 4139 El Camino Way, P.O. Box 10139, Palo Alto, CA 94303-0139, USA : 345-67.

García, Ofelia, and Patricia Velasco. 2012. "Insufficient Language Education Policy: Intercultural Bilingual Education in Chiapas.” Diaspora, Indigenous, and Minority Education 6 (1): 1-18.

Hale, Charles R. 2005. "Neoliberal Multiculturalism : The Remaking of Cultural Rights and Racial Dominance in Central America.” Political and Legal Anthropology Review 28 (1): $10-28$.

Hamel, Rainer Enrique. 2008. “Indigenous Language Policy and Education in Mexico.” In Encyclopedia of Language and Education, Volume 1: Language Policy and Political Issues in Education, edited by Stephen May and Nancy H. Hornberger, 2nd Editio, 1:301-13. 2008: Springer. 
Heath, Shirley Brice. 1972. Telling Tongues: Language Policy in Mexico, Colony to Nation. New York: Teachers College Press.

—. 1982. "What No Bedtime Story Means: Narrative Skills at Home and School." Language in Society 11: 49-76.

Heller, Monica. 1999. Linguistic Minorities and Modernity: A Sociolinguistic Ethnography. London: Longman.

Hinton, Leanne. 2013. Bringing Our Languages Home: Language Revitalization for Families. Berkeley, CA: Heyday Books.

Hornberger, Nancy H. 1991. "Extending Enrichment Bilingual Education: Revisiting Typologies and Redirecting Policy.” In Bilingual Education: Focusschrift in Honor of Joshua A. Fishman. Volume 1, edited by Ofelia García, 215-34. Philadelphia: John Benjamins Publishing Company.

Hornberger, Nancy H., Haley De Korne, and Miranda Weinberg. 2016. "Ways of Talking (and Acting) About Language Reclamation: An Ethnographic Perspective on Learning Lenape in Pennsylvania." Journal of Language, Identity \& Education 15 (1): 44-58.

Hymes, Dell. 1980. “Ethnographic Monitoring.” In Language in Education: Ethnolinguistic Essays, 104-18. Washington, D.C.: Center for Applied Linguistics.

Instituto Nacional de Lenguas Indígenas (INALI). 2008. “Catalogo de Las Lenguas Indígenas Nacionales: Variantes Lingüísticas de México Con Sus Autodenominaciones Y Referencias Geoestadísticas." http://www.inali.gob.mx/clin-inali/.

Jaffe, Alexandra. 2003. 'Misrecognition Unmasked? ‘Polynomic' Language, Expert Statuses and 
Orthographic Practices in Corsican Schools.” Pragmatics International Pragmatics Association 134: 515-37.

la Cruz, Víctor de. 2008. Mapas Genealógicos Del Istmo Oaxaqueño. Oaxaca, Mexico: Culturas Populares, CONACULTA.

Ley General de Derechos Lingüísticos de Los Pueblos Indígenas. 2003. Mexico.

http://www.diputados.gob.mx/LeyesBiblio/pdf/257.pdf.

López-Gopar, Mario E., Narcedalia Jiménez Morales, and Arcadio Delgado Jiménez. 2014.

“Critical Classroom Practices: Using ‘English’ to Foster Minoritized Languages and

Cultures in Oaxaca, Mexico." In Minority Languages and Multilingual Education, edited by

Dirk Gorter, V. Zenotz, and Jasone Cenoz, 177-99. Dordrecht: Springer.

López-Gopar, Mario E., Omar Núñez-Méndez, William Sughrua, and Angeles Clemente. 2013.

“In Pursuit of Multilingual Practices: Ethnographic Accounts of Teaching 'English' to

Mexican Children." International Journal of Multilingualism 10 (3). Routledge: 273-91.

López-Gopar, Mario E., and William Sughrua. 2014. "Social Class in English Language

Education in Oaxaca, Mexico.” Journal of Language, Identity \& Education 13 (2).

Routledge: 104-10.

López Gopar, Mario. 2016. Decolonizing Primary English Language Teaching. Bristol, UK: Multilingual Matters.

López Gopar, Mario E. 2007. “El Alfabeto Marginante En La Educación Indígena: El Potencial de Las Multilectoescrituras." Lectura Y Vida September: 48-57.

Makoni, Sinfree, and Alastair Pennycook, eds. 2007. Disinventing and Reconstituting 
Languages. Bristol: Multilingual Matters.

Maldonado Alvarado, Benjamín. 2002. Los Indios En Las Aulas: Dinamica de Dominación Y Resistencia En Oaxaca. Mexico, D.F.: Instituto Nacional de Antropologia y Historia.

Marcellesi, J. B. 1983. "Identité Linguistique, Exclamatives et Subordonnées: Un Modèle Syntaxique Spécifique En Corse.” Études Corses 20-21: 399-424.

McIntyre, A. 2008. Participatory Action Research. Thousand Oaks, CA: Sage.

Mendoza-Mori, Américo. 2017. "Quechua Language Programs in the United States: Cultural Hubs for Indigenous Cultures." Chiricú Journal: Latina/o Literatures, Arts, and Cultures 1 (2): 43 .

Overmyer-Velázquez, Rebecca. 2010. Folkloric Poverty: Neoliberal Multiculturalism in Mexico. University Park, PA: Pennsylvania State University Press.

Pennycook, Alastair. 2001. Critical Applied Linguistics. UK: Lawrence Erlbaum Associates Publishers.

Pérez Báez, Gabriela. 2015. Cuaderno de Lectoescritura Del Zapoteco Del Istmo. Washington, D.C.: Smithsonian Institution Press.

Pérez Báez, Gabriela, Victor Cata, and Juan José Bueno Holle. 2015. “Xneza Diidxazá: Retos En La Escritura Del Zapteco Del Istmo Vistos Desde El Texto Teria.” Tlalocan XX: 135-72.

Pickett, Velma B. 1993. "Reflexiones Históricas Sobre La Ortografía Del Zapoteco Del Istmo." Guchachi Reza 42: 27-30.

Pickett, Velma B., Cheryl Black, and Vincente Marcial Cerqueda. 2001. Gramatica Popular Del 
Zapoteco Del Istmo. 2nd Editio. Instituto Linguistico de Verano.

www.sil.org/mexico/zapoteca/istmo/G023a-GramaticaZapIstmo-ZAI.htm.

Pietikäinen, Sari, Helen Kelly-Holmes, Alexandra M. (Alexandra Mystra) Jaffe, and Nikolas Coupland. (2016). Sociolinguistics from the Periphery: Small Languages in New Circumstances. Cambridge, UK: Cambridge University Press.

Piller, Ingrid. 2016. Linguistic Diversity and Social Justice : An Introduction to Applied Sociolinguistics. Oxford, UK: Oxford University Press.

Romero Frizzi, María de los Angeles. 2003. Escritura Zapoteca: 2500 Años de Historia. Mexico, D.F.: INAH CONACULTA.

Skutnabb-Kangas, Tove, and R. Phillipson. 1994. Linguistic Human Rights: Overcoming Linguistic Discrimination. Berlin: Mouton de Gruyter.

Sociedad Pro-Planeación del Istmo, La. 1956. “Alfabeto Popular Para La Escritura de Zapoteco Del Istmo.” Mexico, D.F. http://www.sil.org/system/files/reapdata/18/46/28/184628526631397431774562962931659 96711/L073_AlfPopZapIstmoFacs_zai.pdf.

Tollefson, James. 1991. Planning Language, Planning Inequality. London: Longman.

Whitinui, Paul, Maria del Carmen Rodríguez de France, and Onowa McIvor, eds. 2018. Promising Practices in Indigenous Teacher Education. Singapore: Springer Nature.

Zavala, Virginia. 2013. “An Ancestral Language to Speak with the 'Other': Closing down Ideological Spaces of a Language Policy in the Peruvian Andes." Language Policy 13 (1): $1-20$. 
